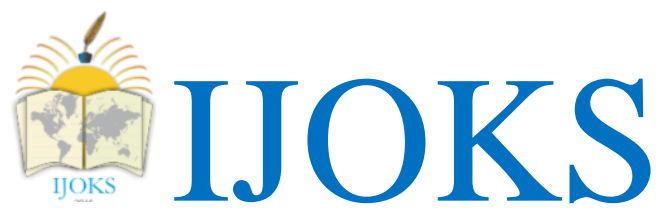

International Journal of Kurdish Studies

(ISSN:2149-2751)

5 (1), pp. $41-52$

http://www.ijoks.com

\title{
Kurdish Image in Novels of Early Period of Turkish Republic
}

\section{Şener Şükrü YİĞITLER ${ }^{1}$}

Received: Oct 28, 2018 Reviewed: Nov 29, 2018 Accepted: Dec 02, 2018

\begin{abstract}
This article examines the representation of Kurdish people in novels written during the early Turkish Republic period. Turkish literature in the early years of the newborn republic produced works in line with official discourse and state policies; the novel was the most popular art form and a convenient means of propaganda. The Kurdish question, which remains unresolved to this day, has its roots in the establishment of the Turkish republic. Being the most resistant minority group before the nation-state project in this period, Kurds were considered a national security threat, and their demands were made a part of the "securitization" policies of the nation-state process. Accordingly, in fiction, Kurds were only referenced in the context of Kurdish rebellions that took place in the early years of the republic. They were represented as "bandits" and "reactionaries" in novels dealing with them, which were already too few in number.
\end{abstract}

Key words: Early period of Turkish Republic, Novel, Rebellion, Reactionism, Literature

Recommended citation:

Yiğitler, Ş.Ş. (2019). Kurdish Image in Novels of Early Period of Turkish Republic. International Journal of Kurdish Studies 5 (1), 41 - 52 DOI: 10.21600/ ijoks.516478

\section{Introduction}

Turkish government implemented disciplinary operations ("tedip"), assimilation ("temsil"), banishment ("tenkil") practices in Eastern provinces in 1930s. Just before the said period, Kemalists had become the only power by enforcing Law on the Maintenance of Order (“Takrir-i Sükûn Kanunu”, 1925) and Eastern Reformation Plan (“Şark Islahat Planı”, 1925) (Bayrak, 2013: 149-164 and Yeğen, 2011: 163-174) bringing all political opponents to trial in Independence Courts ("Istiklal Mahkemeleri"). This "elite/intellectual" ruling class, most of whom had military origins, regarded their opponents as the primary danger for the regime and

\footnotetext{
${ }^{1}$ Research Assistant Doctor., Bitlis Eren University, Faculty of Sciences and Literature, Department of Turkish Language and Literature, ssyigitler@gmail.com, ORCID NO : https://orcid.org/0000-0002-7283-3621
} 
implemented strict measures to crush them. As a result, all kinds of "securitization" approaches to Eastern provinces, the concentration areas of religious people and Kurds, ruled every aspect of life, daily politics being in the first place, and thus, helped rise of an highly "guided literature" (Türkeş 2002: 425-448).

Kemalist nation-state formation process contained the Muslim minority groups as well as the non-Muslim minorities, and paid special heed to appear that it was interested in "Muslim" identity of these groups while absorbing them in its monolithic structure. Muslim minorities, hereby, were evaluated in religious context, and not included in ethnic minorities described in Treaty of Lausanne, July 24, 1923. (Oran 2015: 63-64). This helped the government highlight only the religious side of all kinds of resistance of Kurds against the new regime. For example, Sheikh Said Rebellion, 1925, meant nothing but a trivial uprising that could be ignored or in the worst case, crushed with the recognition of "Turkish power" for the Republican elite, who vindicated a radical secularism and westernization, and cherished the new regime and its ideals with pride and enthusiasm.

Kurdish image in Turkish literature is discussed in some significant works (Yücel 2011; Türkeş 2011), though with some deficiencies, most of which are some unknown and obsolete novels. We will try to give a full list of the novels on Kurds and description of the approach to the Kurds in early Turkish Republic period.

\section{A people in rebellion}

Though Halide Edip Adivar left Turkey in 1926 and could not celebrate tenth anniversary of Turkish Republic within the borders of the country because of political conflicts she and her husband, Adnan Adivar, had with Ankara government, she wrote her books in the service of the new regime before and right after the proclamation of the Republic. Halide Edip, in her novels Kalp Ağrısı (Heartache, 1924) and its sequel Zeyno'nun Oğlu (Zeyno's Son, 1928), where she tangles a complex men-women relationship in an Istanbul-Diyarbakır line, problematizes a series of Kurdish rebellions against the new regime and disciplinebanishment operations that took place between 1924 and 1928. Tan1l Bora, in his article which examines the "Kurdish image" in the two-book-sequel states that Halide Edip, in contrast to her contemporaries, most of whom could be defined as "regime's official or loyal writers", clearly articulated the national name, "Kurds", for the local people, and implicated discipline-banishment measures could not resolve the problem. Though, despite her critical point of view, Bora also shows Halide Edip does not strongly diverge from the official Kurdish policies of the time (2014: 61-65). Indeed, in Halide Edip's novels which almost 
have a touch of orientalist tourist guide about Diyarbakır, defined as a "feudal land", "hot and exotic", "mysterious and magical" and "the land of mystery and horror"i (Adivar, 2010: 129, $241,217,218$ ) and Kurds she seems willing to repeat the "ignorant, religious and uncivilized" Kurdish image establishing a Turkish man-Kurdish woman relationship, which seems to be essential in novels handling Kurdish Question. There are two main women characters in Zeyno'nun Oğlu: first, Kurdish Zeyno from Diyarbakır, and second, Zeyno of Istanbul, who is a half Kurdish-half Turkish young woman bred in Istanbul and almost the antagonist of the first one. Kurdish Zeyno (or Zeyno of Diyarbakır), called by soldiers in the headquarters as "Kurdish Peach", becomes the object of an erotic picture formed with racial determinations like "a round mole right on the tip of her lips" and "slim, straight and black eyebrows, which only could be seen in Kurdish people, leaning over hot, reddish cheeks, in fact, just like peaches" (Adivar, 2010: 243). Kurdish Zeyno's sexual attraction is enhanced with her spiritual weakness and loyalty before Captain Hasan. Kurdish Zeyno "worships him like a God" (Adıvar, 2010: 71) "her fiery dependence and worshipping" (Adivar 2011: 255) symbolizes the obedience of the woman, who stands for "the desolate and far away countries" (Adivar, 2010: 102) to the man, both a soldier and Turk. Though they are thoroughly different, common point of two women is the loyalty to the soldiers; semi-Kurdish Zeyno of Istanbul "has grown a peculiar weakness for uniform." "Soldiers, officers, all of them, always rouse a palpitating, sweet or bitter, feeling in her" (Adıvar, 2010: 195).

Despite the evaluation above, we need to state that ethnic emphasis is more explicit in Kalp A $\breve{g r l s l}$ (1924), compared with religious content in Zeyno'nun Oğlu (1928). Protagonist of the novel is “...Zeynep; her father calls her 'Zeyno' as her grandfather is Kurdish, and young girl inherits a boiling temperament and passion from the racial fire of the same grandfather, which is only known to her father" (Adivar, 2011: 14). In another example Zeynep, modernized in Istanbul and thus Turkified, and Captain Hasan have the conversation below when they first meet:

"-You know my name, as well. What is your name?

-Zeyno.

-Gee! You must be a Kurdish youth.

-No, I am a Turkish youth, who is Kurdish, if I could still be taken young,"ii (2011: 20).

This dialog reflects the policies behind the determination to call people with different ethnicities living in Turkey as "Turk." This approach becomes even more evident in physical 
and moral development of another character, the "Kurdish child" Haso. Born of Kurdish Zeyno, begotten of Captain Hasan, Haso the Child is the "most victorious sample of natural selection which combines most beautiful parts of a most beautiful Kurdish woman and a handsome Turkish man" (Adıvar, 2010: 71). As seen here, personality is determined by racial prejudices; the child "looks like the offspring of a thoughtful species, not a fiery one" (Adivar, 2010: 204). In other words, he is too thoughtful to be a Kurd. Indeed, at the end of the novel it turns out Captain Hasan is his real father. Long before appearance of Captain Hasan as the father of Haso the Child, we see that a Turkish man called Şaban brings him up. Şaban “comes from a Turkish family whose grandfather migrated to K... Village from Kemah and keeps silence and sweetness of Eastern Turks in his temperament -despite the fiery Kurdish blood from mother's side" (Adıvar, 2010: 70). When Haso the Child, though he is against discriminating people, compares his mother and Şaban, he easily discerns between "fiery manners and noises" of the Kurds, and "more tranquil and controlled manners" of the Turks. His closeness to Kurdish people is "just because of his dependence on his mother" (Adivar, 2010: 135). His ability to perceive "loud voices of Kurdish from gentle and soft voices of Turkish" (Adivar, 2010: 137) shows his perceptive readiness for a nationalistic awakening. The only thing he needs, now it appears, is the available conditions for a good education. Zeyno of Istanbul, who is married to Colonel Muhsin, adopts Haso the Child at the end of the novel. In this way, a useful solution for the upbringing of Haso the Child (as his name equates childness and Kurdishness) is found: "Let that Zeyno be your real mother, and this Zeyno be your intellectual mother. What do you say?" Haso the Child, of course, accepts this offer without hesitation. This quotation could also be read as a literary solution by Halide Edip, who foresees Kurdish people could be included in nation-state process with assimilation practices rather than discipline-banishment operations.

Halide Edip, who covered Sheikh Said Rebellion in her abovementioned books, continued the story of a group of modern elite in Diyarbakır in her book Zeyno'nun Oğlu (1928) from the point she left in Kalp A $\breve{g r l s l}$ (1924). Zeyno'nun Oğlu (1928) is more agitative and propagandist than the first novel in every sense. We stated that Halide Edip differed from her contemporaries in mentioning the name of Kurds, actors of the rebellions. In her novel Zeyno'nun Oğlu, she sets the plot of her novel available for declaring her views on Sheikh Said Rebellion and adds new characters in the fiction. For example Sheikh Mecit, who employed Haso the Child in order to train him in horse races, is a man, "who was thrilled with Sakarya War, and seemed to give up Kurdish case, which he once followed" (Adıvar, 2010: 
117). The sheikh, who returned to his "self" after euphoria of the victory abated, tells the little child that Turkish soldiers and officers are "cruel and irreligious", and "Kurds are people of God and Turks are the creatures whom He will scourge" (Adivar, 2010: 134, 176). His statements about "the society who wore low-cut dresses even in the mornings and frock coats in evenings" (Adivar, 2010: 163) and, in other words, Istanbulites who created a "Diyarbakir high society" (Adıvar, 2010: 284) are equally harsh:

"For one thing, sheikh told that Istanbulites were cruel, evil and bad people, and God took him into His service to punish them. (...) The sheikh, especially, compared Istanbulites with the people of Lut and gave odd examples from their lives." (2010: 282)

Depending on the sound similarity established between the names, it could be alleged that Halide Edip, here, indirectly refers to Sheikh Said. Throughout Zeyno'nun Oğlu she shadows out Kurdish people rise up with religious feelings, rather than nationalist motives. In this point Halide Edip shares the official-nationalist assumption: Kurdish people, accordingly, do not have a national cause/consciousness in these revolts; they only endeavor to keep their feudal order in the region, which is highly religion based. The official nationalism in Early Period Republic, that views minority groups' nationalism as a security threat, handles Kurdish revolts with military measures and this is another topic which Halide Edip prefers self-censor and join in the national ideology of the period. In the last chapter of the novel titled "After the Storm" ("Firtınadan Sonra") Muhsin Bey tells his wife Zeyno that "Human storm of the East hit and passed over Diyarbakır. Being one of those engaged in putting out a disastrous fire as long as it continued made me ignore you for the first time ever" (Adivar, 2010: 329). Consequently, first and one of the most serious occurrences of the Kurdish Question, which continues being an unsolvable problem of new-born Turkey, ${ }^{\text {iii }}$ is a matter that could be handled with soldiers' self-sacrifice and is a storm that "hits and passes."

Early Republic's military/civil authorities evaluated the incidents in Kurdish cities as a matter of security and called the rebels "a group of ungrateful people and bandits." This was a nationalist defense mechanism to avoid real content of the events, and served as a mainstay for the discipline-banishment operations in the region. Early Republic period literature, as shown in the example above that regarded Kurdish Question as a storm that "hits and passes", was a highly dutiful literature that produced popular romances that thrived with self-evident theories about modernization, secularization, women emancipation, and more aesthetic/canonic novels which covered such topics inherited from the empire like 
intellectuals-people conflict, minorities, war profiteers and Ottoman dynasty in compliance with official ideology.

\section{Kurdish image in novels}

Another remarkable point with the minorities is their representation in the literature of the period. Prompting the new born nation-state's threat perception in many occasions, Kurds ranked high in the list of "nation's enemies" together with Armenians, Greeks and Jews; however, as it seems, they were not a fruitful literary material in literature as aforementioned minorities. The reason of this silence, mostly negligent, was the country-wide censorship implemented for the policies in eastern cities and the "banditry" and "separatism" discourses developed against the struggle for Kurdish rights and freedom and successfully handed down to today's politicians by the said period's rulers. As much as Kurds represented a past which is mingled with religion and thereupon must be left behind for secularist/modernist republican elites, this could be seen in innumerous example in period's literature, they were used to depict "uncivilized, brutal, ignorant and non-ideal" citizens of pre-republic times. A persona non grata image was invented and employed for Kurds so that the "modern, secular and civilized" Turk, an image that inevitably reminds "the white man of Asia Minor", could shine and stand out more among the other nations of Anatolia. The origins of this representation could be found in Turkish History Thesis. Scientists, some of whom were theoreticians of Republican People's Party at the same time (Beşikçi, 1986: 51-50; 151-153), claimed that ancient Turks established and developed a very rich civilization in Middle East; however, they had to left their homeland due to unfavorable climate conditions and migrated all around the world establishing new high civilizations where they settled (for example, in China, India, Egypt, Mesopotamia, Greece and Italy), and Anatolia was only one of these civilizations (1931: 50-58).

With this pseudo-scientific basis, autochthonous nations of Anatolia were extracted from the historic background of Anatolia; in a sense, they were sociologically and politically being disregarded. However, before the proclamation of new regime, for example in the days Mustafa Kemal landed in Samsun and started campaign for national independence, he seems to be very careful to use a pluralist and inclusive language:

"As central government is captive, and capital city is under military occupation, we all recognize that fate of the nation is at the hands of nation's army. Thus, I am determined to unite Kurds and, also, all nation 
together and achieve this through Associations for Defense of National

Rights (“Müdafaa-1 Hukuk-u Milliye Cemiyetleri”)" (1991: 37).

After completing the religious disintegration provided by Treaty of Lausanne (1923) and its subsidiary population exchange clauses, the republican regime established following the Turkish National Struggle, as stated before, by-passed the concept of religion by force of secularization process, and went about utilization of ethnicity. With this, one more step was taken towards nation-state process, which had long been started by Committee of Union and Progress ("İttihat ve Terakki Cemiyeti”), holding power after proclamation of Constitutional Monarchy Period (1908) and especially with 1913 Ottoman coup d'état, and implemented pan-Turkist/nationalist policies throughout World War I. (Dündar, 2015: 57-62). Those who could not be separated by their religious believes were strained by their blood/breed/race, and, as a result, they were either expected to be "assimilated" or the government resolved to military measures, in which army was called out, and every kind of violence acts were legalized. After Sheikh Said Rebellion (1925), first massive insurgence in Republic history, was quelled with a crushing strength, and the rebellions were tried in Independence Courts (“İstiklal Mahkemeleri”), and sentenced to capital punishment, the army was given more crucial missions in Ağrı Rebellion (1926-1930) and Dersim Military Operation (1937-1938).

Literature in Early Period Republic we have alleged here to lapse into silence about Kurdish people has approached them in relation with rebellions when it has dealt with them with a limited number of novels. In this sense, we may speak of a "Kurd-rebel-bandit" association in the minds of the authors in the period. We have seen that first novels to tell about Kurds and Kurdish rebellions were written by Halide Edip, who dealt with most contradictive matters of Committee of Union and Progress and early Turkish Republic periods and thus excluded by both governments. In these novels, Kurdish people are depicted as a nation, victimized as a result of Islam and their collective ignorance. They are easily deceived as they live in caves and on the top of mountains, deprived of civilization and human values. For example, in Dünkülerin Romanı (Novel of the Past, 1934), after mentioning Armenians' education in American colleges, Burhan Cahit Morkaya refers to Kurds over geographical implications, needless to say, without stating name of a nation: "Ahead of us, those who spend their lives in the rocky holes of Dersim Mountains and those who are trained under American education are like people of other climates, other countries" (Morkaya 1934: 127). Here, it is implied Kurds are incompatible with modern nation definition. Esat Mahmut Karakurt's Dağları Bekleyen Kız (The Girl Who Guarded Mountains, 1934) differs from its 
counterparts by directly dealing with Ağrı Rebellion. While telling about the love between Captain Adnan, a fighter pilot, whom the author of the book burdens every aspect of modern Turkish image, and Kurdish beauty Zeynep, Kurdish people become the target of various humiliation, mostly racial. A derogatory and gloomy depiction starts from the very beginning of the novel: "This middle age town with its homes made of manure, its narrow and muddy streets where a mule could barely pass, perhaps, is experiencing historic days it hasn't gone through since its creation" (Karakurt, 2009: 7). Such sentences like "Ridges of that region which, perhaps, have been dark since their first creation were lighted up as it was daytime" and "There is no light in the streets. City, immersed in terrible darks that carried mystery of middle ages, is going through a mystery night" (Karakurt, 2009: 15, 20) depicts the eastern part of the country as an uncivilized land of savages. In Karakurt's novel, people of the region are as wild as the geography they live in. Captain Adnan, the protagonist of the Dağlart Bekleyen Klz asks Sergeant Ahmet, his friend who have been captured by rebels: "Sergeant, these men are very wild, aren't they?" The answer he receives for his question is a striking example of the republican viewpoint on Kurds:

"Sir, what is wild? One detests humanity among these. Such ferocity, cruelty and dishonor cannot be witnessed. They think of the price of the bullet, not the value of one's life, while killing. They have no religion, no belief, no God... They believe in nothing. You see, and look for people to kill in these godforsaken mountains with underpants on their legs, felt cones on their heads. What they eat is a morsel of meat and bulgur. (...) Each has five to ten wives. Some of them still strangle their daughters. They know no home, no place, no conscience. They live in caves, in dens they burry under earth, and under boulders. They know no military service, no homeland. Only one thing! They only know and recognize their sheikh. What he orders is done at once. As I said, these are not human. These are such creatures hard to name." (2009: 67)

This dialogue gives away the subtle contention of republican intellectuals felt of themselves that they were ultimately modernized/westernized, comparing with the "brutal" and "wild" Kurdish image, which was very common in the period. In Karakurt's novel, Kurdish people are only called "bandits" and "brigands in mountains." We see another example of this in Orhan Rahmi Gökçe's novel, Bir Şüphenin Romanı (Novel of a Suspicion, 1934). Though its subject and content matters are totally irrelevant, Kurds, whom the author refers to as 
"bandits" (Gökçe, 1944: 107-109) throughout the novel, appear with an eastern mission given to protagonist of the novel, İrfan, during his military service, which has no discernable contribution in the plot. Thus the novel, which predominantly takes place in Izmir-AnkaraIstanbul triangle, stops by Dersim, former name of Tunceli province before the Tunceli Law (1935). In the beginning of the novel, İrfan, who postpones his military service due to pleurisy, goes to Ankara by train in order to learn about his first place of duty, and falls in love with a woman called Süheyla. The young lovers spend a short but dreamlike time together in Ankara. However, after a terrible traffic accident they lose each other. Irfan stays in a hospital for a time. After recovering, he starts teaching in a school in Izmir. Then, he returns to Ankara for medical examination required for his military service. İrfan, who "has always been postponed due to a physical weakness", now feels betters and says "This is service, of course, I'll join" (Gökçe, 1944: 89) when he first finds out he is called out. After a stressful medical examination, İrfan is commissioned as reserve officer (Gökçe, 1944: 92). This is the point where Dersim setting comes into play. In Dersim, İrfan joins in military operations carried out against Kurdish rebels, about whom he thinks to be "wild, perverse and undaunted" (Gökçe, 1944: 108). In one of these operations, Irfan goes after a woman who kills Sergeant Ömer, closest comrade of Irfan. After a long chase and gunfight, the woman kills herself in order not to be captured. İrfan has a nervous breakdown because of her resemblance to Süheyla. Then he is discharged for treatment. He hears from Süheyla during his stay in hospital, and returns to Izmir after he gets well. Here, they reunite and start a happy family. After a while, they have a child named Ayhan, who is almost three years old. Everything looks fine for the small family. However, Irfan suspects the paternity of the child. He thinks the father of the child is Memduh, a close family friend. In another nervous breakdown, Irfan tries to kill Ayhan. In the end, the truth is revealed and Irfan understands he is the real father. Though the reason why Orhan Rahmi added Dersim chapter (pages 99-118) is uncertain, there is no doubt he had the chance to reflect the official approach of the period to Kurds.

\section{Turkish man/soldier and Kurdish woman}

Yücel, who also studied Kurdish image in Turkish cinema, finds it very interesting the way Turkish literature and cinema are interlinked in their approach to Kurds. Yücel states that Kurdish people were represented only by "woman image” for a very long time. (2008: 250). Another remarkable point in novels is, as Ömer Türkeş (2011) pointed out, "the metaphoric humiliation in which man represents the strong nation, and the woman represents the weak." 
This a priori and deterministic/teleologic pattern could be found in every novel related with Kurds and Kurdish rebellions. Mükerrem Kamil Su, like Esat Mahmut Karakurt, tells a love story using Ağrı Rebellion as the background in her Sevgim ve Istırabım (My Love and Ordeal, 1936). In this novel, there are two women, one Turkish and one Kurdish, in love with the same soldier. However, the formula, in which a submissive Kurdish woman unconditionally commits herself to a Turkish soldier and the common use of which we have seen in novels examined in this article (Zeyno'nun Ŏglu, Hasan-Zeyno; Dağları Bekleyen Kız, Adnan-Zeynep), is repeated by Mükerrem Kamil in this novel, as well. Gülseren is a smart and successful senior student, engaged with Metin, a courageous fighter pilot. They get engaged before Metin is taken into service in the military unit sent to the eastern part of the country for the ongoing Kurdish rebellion. Gülseren reads from the newspapers that Metin's warplane has crushed and her fiancée has been lost. This makes her heart sink for a very long time. After Ağrı Rebellion is squashed, all truth comes out with a letter from Metin. In his letter, Metin tells that he loved a woman, and he fell in love with Gülseren due to her very likeness with that woman, and he chose military so that he could forget his ex-love. He is saved by an unnamed Kurdish woman after his plane crushed. Her loyalty is depicted by Metin as follows: "Because of her heartrending submission, I couldn't let her go. I became an elder brother to her. I lived with this desperate girl, who followed me like a faithful slave for

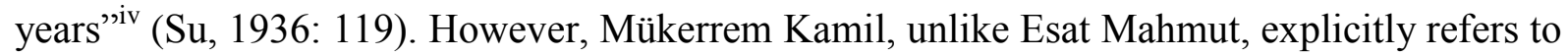
Kurds, calling them "reactionary". By this, she carries them out of ethnic context into religious context with common connotations. Gülseren, the female protagonist, sighs after his fiancée saying, "East Rebellion... Oh, these reactionary Kurds... This beheaded boil needs rooting away before it becomes gangrenous"” ( $\mathrm{Su}, 1936: 53)$. As Füsun Üstel put forward, "the statement 'bandits in mountains' referred to the Kurdish Question, which Turkish Republic had to face; however, the problem was degraded to an ordinary crime or a general security matter" (2013: 46).

\section{Conclusion}

As is seen, though Kurdish people are barely covered in literature of Early Turkish Republic Period, they are dealt in the context of uncivilization and rebellions. In other words, there is an implicit identification between Kurds and reactionism, banditry and rebels, vehemently supported by republican authorities, and subtly established by the authors of the time. ${ }^{\mathrm{vi}}$ Novels on Kurdish rebellions like Zeyno'nun Oğlu, Bir Şüphenin Romanı and Sevgim ve 
Istırabım mainly relies on the hostilization of Kurds. The geography described in these novels is also hostile, savage and uninhabitable, representing the character of the people living in these regions. As told in Dünkülerin Romanı by Morkaya, Kurds are uneducated and wild people, who resist all aspects of morals and civilization. In almost every novel of the period dealing with Kurds, there is a civilization-reactionism conflict established through an imaginary Turkish officer-Kurdish woman relation as in Zeyno'nun Oğlu, Dağlarl Bekleyen $K ı z$ and Sevgim ve Istırabım. These novels, each functioning as the vanguards of Turkish modernization in eastern Turkey, endeavor to absorb all elements that seem to hinder nationstate process, and propagandize discipline/banishment reinforced assimilation methods and military operations.

We may conclude that Kurdish image in the novels written in the early Turkish Republic period is formed by and loaded with a male-dominant and orientalist approach of the modern/secular nation-state trying to establish its own east in the eastern cities of Turkey.

\section{References}

Adıvar, H. E. (2011) Kalp ăgrısı. İstanbul: Can.

Adıvar, H. E. (2010) Zeyno’nun oğlu. İstanbul: Can.

Alakom, R. (Ed.) (2011) Bir Türk subayının Ă̆rı isyanı anıları. İstanbul: Avesta.

Bayrak, M. (2013) Kürtlere vurulan kelepçe şark ıslahat planı. Ankara: Özge.

Beşikçi, İ. (1986) Türk tarih tezi ve Kürt sorunu. Stockholm: Dengé Komal.

Bora, T. (2014) 'Hey Zeyno, Zeyno' Halide Edip'in romanlarında Kürt imgesi. Birikim Dergisi, S. 307, November: 61-65.

Bozdağ, İ. (2004) Kürt isyanlarl. İstanbul: Truva.

Dündar, F. (2015) Modern Türkiye'nin şifresi, Ittihat ve Terakki'nin etnisite mühendisliği (1913-1918), İstanbul: İletişim.

Gökçe O. R., (1944) Bir şüphenin romanı. İstanbul: Uğur Kitabevi.

Karakurt, E. M. (2009) Dă̆ları bekleyen kız. İstanbul: Bilgi.

Milli mücadelede Kürtler. Atatürk'ün tamim, telgraf ve beyannameleri IV (1991), Ankara.: Atatürk Kültür, Dil ve Tarih Yüksek Kurumu Atatürk Araştırma Merkezi.

Morkaya, B. C. (1934) Dünkülerin romanı. İstanbul: Kanaat Kütüphanesi.

Oran, B. (2015) Türkiye'de azınlıklar kavramlar, teori, Lozan, iç mevzuat, içtihat, uygulama. İstanbul: İletişim.

Su, M. K. (1936) Sevgim ve tstırabım. İstanbul: Yeni Kitapçı.

Timuroğlu, V. (1991) Dersim tarihi. Ankara: Yurt Yayınları.

Türk tarihinin ana hatları: methal kısmı (1931). İstanbul: Maarif Vekâleti. 
Türkeş, Ö. (2011) Dersim dört dă̆ içinde. Radikal Kitap. Http://Www.Radikal.Com.Tr/Kitap/Dersim-Dort-Dag-Icinde-1071978/ (accessed in 27 November 2016).

Türkeş, Ö. (2002) Güdük bir edebiyat kanonu. Kemalizm, modern Türkiye'de siyasi düşünce, Cilt 2, Istanbul: Iletişim.

Üstel, F. (2013) Bir vatandaşlık projesi olarak Kemalizm. Resmi ideoloji ve Kemalizm. İstanbul: Ceylan.

Yeğen, M. (2011) Son Kürt isyanı. İstanbul: İletişim.

Yücel, M. (2008) Türk sinemasında Kürtler. İstanbul: Agora Kitaplı̆̆ı.

Yücel, M. (2011) Osmanlı-Türk romanında Kürt imgesi. İstanbul: Agora Kitaplığı.

\footnotetext{
${ }^{\mathrm{i}}$ All quotations herein are translated by the author of the article.

${ }^{i i}$ In Zeyno'nun Oğlu, Zeynep of Istanbul and Haso the Child have a similar conversation. Zeynep says: "My name is Zeyno as well, my boy. -Are you Kurdish, ma'am? -A little, my boy...” (p. 175).

${ }^{i i i}$ We need to state that this reactionism and religion emphasis in Kurdish Movement used by official discourse has quite been reversed in recent years. Beginning from 1980s Kurdish Movement has been linked with Marxist, atheist and separatist thoughts with a strong a national cause/consciousness aiming against national unity of Turkey. For more information see Yeğen M (2011) Son Kürt İsyanı. İstanbul: İletişim Yay.: 117-133.

${ }^{\text {iv }}$ Emphasis added.

${ }^{\mathrm{v}}$ Emphasis added.

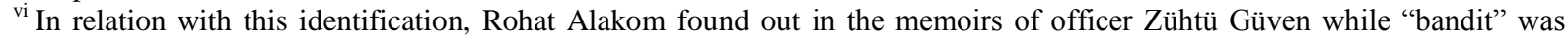
used for 375 times, "Kurdish" took place for 70 times. Alakom R (ed.) (2011). Bir Türk Subayının A ğrı İsyanı Anıları. İstanbul: Avesta Yay.: 11.
} 